Robert Rattle:

\title{
ICTs, Values and Social Change: The Case of Canadian Democracy
}

\begin{abstract}
:
Internet and communication technologies (ICTs) are revolutionising how people communicate and connect. While these have catalyzed calls for increasing societal change, social messages, not the technologies, motivate these actions. This paper will use the case study of Canada and the application of ICTs to argue why they are no less likely to support social change in modern economies than any previous technology. Drawing on examples of federal policy changes in Canada, the paper will argue ICTs and social media can be used to suppress democracy, undermine science and expand social impacts, even where they are intended to specifically address those problems. The paper will then discuss the roles of values in social change to argue that ICTs and social media are influenced by larger societal forces and that these are often better predictors of outcomes than the application of any one technology for social change.
\end{abstract}

\section{Agenda:}

Introduction

Canada - A Modern Democracy?

Public Broadcasting

Scientific Information

Environmental and Social Justice

Social change - New ICTs and Values.

Conclusion

Author:

Robert Rattle:

- Independent Scholar/Sault College, 736A Queen Street East, Sault Ste. Marie, Ontario, Canada

- +001 705945 1573, robert14robert@yahoo

- Relevant publications

- $\quad$ Rattle, Robert (2010). Computing Our Way To Paradise: The Role of Internet and Communications Technologies in Sustainable Consumption and Globalization, Richard Wilk and Josiah Heyman (series editors), Altamira Press, January 2010.

- $\quad$ Rattle, Robert (2011), Computing Our Way to Paradise in Westra, Laura, Bosselmann, Klaus and Soskolne, Colin. (eds.) Globalisation and Ecological Integrity in Science and International Law, Cambridge Scholars Publishing.

- $\quad$ Rattle, Robert (2012), Smart Grids, Internet Technology and Informational Role in Environmental Sociology, in Cudlinova, E. and Lapka, Miloslav (eds.), Towards an Environmental Society, Karilonium Press. 


\section{Introduction}

The paper discusses the actions of a western democratic country to affect the use of ICTs in its efforts to expand inequalities, restrict social and environmental protections and weaken democratic participation, demonstrating the capacity to use ICTs to suppress democracy distinct from most enquiries that typically examine actions in less stable political environments. The country examined in this case is Canada - arguably considered a strong western democracy - by considering the pro-authoritarian position of the Canadian federal government in recent years. While many positive applications of ICTs exist that offer evidence of community empowerment, this paper will demonstrate the ability of governments in modern democracies to employ anti-democratic activities if they so choose to support specific ideological beliefs. In this context, ICTs may readily be employed to maintain and even strengthen the status quo despite widespread misconceptions about the empowering nature of ICTs to generate social change. The paper will then discuss the roles of values in social change to argue that ICTs and social media are influenced by larger societal forces and that these are often better predictors of outcomes from social change efforts.

\section{Canada - A Modern Democracy?}

Canada has established a strong public broadcaster (the Canadian Broadcasting Corporation or CBC), a well respected central statistical agency (Statistics Canada or Stats Can), and a reputation for environmental and social practices - such as the Canadian Environmental Assessment Act and Agency - that have placed Canada in a well respected international light and leadership role among its many successes as an advanced economy. The names of Maurice Strong, David Suzuki, Stephen Lewis and many well-known and respected media practitioners (not to mention Marshall McLuhan) are recognised internationally within and outside their circles of influence. These, among many other institutions, have been chief in establishing Canada as a strong democratic nation by virtue of their information and communication properties.

These developments have both reflected and reinforced Canadian values of empathy, cooperation, sustainability, freedoms of expression, strong democratic participation in community life, an important role for the state, and sustainably sharing our combined wealth of natural resources and human capital to make the planet a better place for all.

Yet despite these successes, current federal policies are eroding, dismantling and eliminating a remarkably long list of social and environmental gains made through the last century in Canada. Of particular concern is the escalating war on knowledge (Rabson, 2012; Smith 2012), less science in policy decision making (Goldenberg, 2012), increasing barriers to informed debate (indeed, any debate at all (CBC, 2009; Horter 2012; Reynolds, 2012)) and reduced freedoms of expression. One Canadian Blogger for the Dogwood Institute relates these changes to new media and communication strategies, suggesting that: Prime Minister "Harper knows the news cycle ...will burn through the story quickly and move on.... if he maintains strict message discipline amongst his caucus, silences public servants and limits information..." (Horter, 2012). How is this unfolding in Canada?

\section{Public Broadcasting}

The CBC has seen its budget slashed radically. In the March 2012 budget, the federal government removed $\$ 115$ million in funding over three years from the CBC, an amount that equals $10 \%$ of the Broadcasters dwindling budget (Canada, 2012; CBC, 2012a). This contributed to the prompt elimination of analogue television services (one month earlier than the one year extension granted by the Canadian Radio and Television Commission) impacting $1.7 \%$ - arguably the most vulnerable television viewers - of the Canadian population. The result of budgetary cutbacks to the public broadcaster has had other effects as well, including an ongoing creep of commercialism into the broadcasting programs and platforms of Canadian public broadcasters. "CBC/Radio-Canada will increase its revenues by better leveraging existing television advertising by maximizing the return on its most popular shows. We'll also aggressively pursue digital advertising revenues" (CBC, 2012). These steps have been accompanied by the consolidation of regional services into fewer and larger distribution domains, markedly eroding local content and quality (Hurtig, 2011). The original requirement to move to digital 
transmission in Canada, as in other countries, has been to free transmission space to expand other digital services (CRTC, 2011). "CBC/Radio-Canada is being forced to shut off, sell, or scrap more than 600 transmission sites currently used to give rural Canadians free access to the $\mathrm{CBC}^{\prime \prime}$ (Open Media, nd). Yet as public broadcasters are increasing their levels of commercialisation, and shutting down most digital transmitters, private broadcasters are maintaining their analogue transmission capabilities in areas exempted from the switch. "Big Telecom companies want to swoop in and monopolize rural Canada's digital future" (Open Media, nd). The business case for CBC simply could not be made in any of these markets given budgetary cutbacks. That has left commercial interests as the sole providers of analogue services in these exempted markets. Moscoe and McKercher (2006) attribute these losses to global convergence in pursuit of 'friction-free' capitalism. This specific pursuit is wholly consistent with the values of right leaning politics that advance the notion that free market forces and economic hegemony combined with limited government 'interference' will generate the greatest social good.

The $\mathrm{CBC}$, like all public broadcasters, balanced commercial media interests. However, more than mere convergence, with a deteriorating role for $\mathrm{CBC}$ in Canadian media, the messages are increasingly concentrated, driven by financial interests and conservative values, shifting media from public interest towards market interests. "It's notable that Canadian newspapers invariably refer to the Canadian Centre for Policy Alternatives as "left-wing" or "left-leaning," but they never call the C.D. Howe Institute "right-wing," and rarely describe the far-right Fraser Institute as what it is. Meanwhile, the right-wing Institute for Research on Public Policy is supposedly a "non-partisan think-tank" and, incredibly, the National Citizen's Coalition is also a "non-partisan organization." " writes Mel Hurtig (2011). A 2006 Canadian Senate Report (Senate, 2006) noted that "No real democracy can function without a healthy, diverse and independent news media to inform people about the way their society works. The argument is that, in a democracy, government should foster healthy and independent news media." The reduced ability of CBC to deliver on its mandate is effectively the loss of democracy in Canada in terms of the role of the media. "The results are fewer diverse sources of local information and less public dialogue, which undermines the health of our democracy." (Hurtig, 2011) Despite the one-to-many and many-to-many communications possible from ICTs, their messages are simply being drowned out by the louder corporate messages supported by these federal government policies, undermining community empowerment and advocating the status quo for social conditions.

\section{Scientific Information}

Similarly, Statistics Canada - the central government agency that holds considerable data and information statistics, including advanced methodologies and the personnel and resources to administer complex national surveys and data collection activities - lost, in the same federal 2012 budget, $7.5 \%$, or $\$ 33.9$ million, of its funding which places the jobs of $50 \%$ of its workforce at risk (Chase, 2012; Curry and Grant, 2012; Galloway, 2012; Grant, 2012). This action followed on the heels of the elimination of the mandatory nature of the Long Form Census - Canada's most comprehensive source of national social statistical data used by a wide variety of groups from academics conducting research to better inform policy decision making to social services personnel on the front lines dealing with poverty and crime.

The federal government cited privacy and security concerns supposedly expressed by Canadians (despite a compliance rate nearing $100 \%$ ), as the reason for this significant change to the Long Form Census. With this change, the federal government expects a compliance rate of $50 \%$ at best, placing at risk the validity of future data collected (CPHA, 2010). Despite the dramatic change based largely on expressed privacy concerns, the same federal government then swiftly introduced Bill C-30, commonly referred to as the Internet Surveillance legislation, that allows, among other things, law enforcement personnel to access, preserve and secretly maintain surveillance data without court oversight, enable real-time surveillance among networks, and provide customer information without court oversight (Geist, 2012). The Ontario Privacy Commissioner described the legislation as representing "one of the most invasive threats to our privacy and freedom that I have ever encountered in my 25 years" (OPC, 2012). Despite an avalanche of public outrage and concern over the proposed Bill (including emails, blog sites and social media campaign), political shuffling may yet result in its enactment, and there remain strong assertions from the federal government that this will indeed be the ultimate result (Geist, 
2012a \& 2012b). ICTs provided that avalanche of public and professional dissension, yet the federal government appears poised to use a much more extensive variety of strategies to overcome and ignore that dissension that include, and go far beyond, ICTs alone, dwarfing any efforts of armchair activists.

In the same March 2012 budget, funding for the First Nations Statistical Council, the National Round Table on the Environment and the Economy and the National Welfare Council were also eliminated. The National Roundtable on the Environment and the Economy, established in 1988, is the only national organization with a direct mandate from Parliament to engage Canadians on the topic of sustainable development. Similarly, the National Council of Welfare provided valuable information on issues of poverty for over four decades. Likewise, the First Nations Statistical Institute is a valuable key portal for first-nations communities to access and store data securely and confidentially. In other words, these three cuts alone harm the most vulnerable of Canadians; those with the least political, financial or social power, along with the ability of Canadians to make sound science-based environmental policy decisions. At the same time, the Community Access Program - a federal program to enable vulnerable populations to access the Internet and all Canadians to access it effectively - was also eliminated, saving almost $\$ 8$ million annually. If this seems like federal penny pinching austerity measures at the expense of the most vulnerable, it is. In 2000, personal tax cuts amounted to $\$ 38$ billion dollars, and the current federal government increased those cuts to include $\$ 18$ billion more for corporations, and $\$ 19$ billion more lost revenues by reducing the federal tax on goods and services (Jackson, 2012; Hennessey, 2012). In other words, the wealthy have become more wealthy and powerful, while the vulnerable have seen their resources systematically eliminated and eroded (Brennan, 2012). These moves alone provide a systematic political basis to secure social support for the values manifest in modern market economies (Naiman, 1997; Labonte and Schrecker, 2007). At the same time, public discourse on these matters has been effectively eliminated, slowly eroding and making invisible dissension. These measures greatly reduce the effectiveness of communications media to contribute to the communication, discourse, and distribution of the roles of key social institutions. In so doing, these measures also undermine the ability of Canadians to discuss and reflect upon, and develop evidence-based policies that represent longstanding social values. Discourse about the differential roles of private versus public institutions in key elements of Canadians' social lives have been effectively eclipsed and handed over to the private sector to manage or manipulate as the case may be, creating "a shift to business oriented professionals as managers of health and social service agencies" (Dunlop, 2006). Those most vested in maintaining the status quo in terms of national productivity and the division of labour are now in charge of ensuring a low level of class consciousness in Canada as the "rationale for prioritizing market determinism" (Beresford, 2005).

These actions crystalise trends that suffocate the distributive and empowering nature of ICTs, eclipsing social change through policy actions that undermine the potential of ICTs.

\section{Environmental and Social Justice}

The Canadian Environmental Assessment Agency also lost 75\% of its budget in the last two years. This has been accompanied by a new Canadian Environmental Assessment Act (2012) that narrows the scope of projects to be assessed, shifts the responsibility away from federal authorities, transforms the triggering process to one of a discretionary nature, changes other processes that make its application less effective, introduces new powers of delegation, substitution and equivalency, and provides a much more restricted role for public participation (Ecojustice, 2012). It no longer matters how well connected Canadians might be - their voices have now been severed from the principal environmental assessment decision making process in Canada.

ENGOs and social groups are not only watching their funding eliminated (Ramos and Ron, 2012), they are watching their steps more closely. Increasing compliance activities to clamp down on the political activities of charities has sent a chill among those in the third sector in Canada, warning against any possible actions that may be considered beyond their bounds of tax laws (national or international) or status obligations (Canada, 2012; Hamilton, 2012; McCarthy, 2012). This move has stifled innovation and creativity in the NGO environmental sector in Canada. 
Similarly, since "2006, there has been a gradual tightening of media protocols for federal scientists and other government workers. Researchers ... are now required to direct inquiries to a media-relations office ... journalists have documented several instances in which prominent researchers have been prevented from discussing published, peer-reviewed literature. Policy directives and e-mails ... reveal a confused and Byzantine approach to the press, prioritizing message control and showing little understanding of the importance of the free flow of scientific knowledge" (Nature, 2012). Commentators have likened these actions to a 'war on science' (Suzuki, 2012). Despite the potential for social media and ICTs to contribute to community and national action alike in a timely and effective manner, current federal policies preclude that potential from ever gaining traction.

Regardless the specific mandates of federal agencies, they all performed vital social roles by collecting, analysing, reporting, and communicating important data and information that enabled an informed public and policy discourse throughout Canada. Canadian society has lost key opportunities to develop, communicate and convey critical information consistent with key Canadian values to and from the masses. At a time when ICTs could efficiently facilitate these communications, the institutional and governance structures to enable this potential has been systematically dismantled, ambushed and re-oriented. The ability of ICTs to provide multi-directional communications has been largely reduced from federal processes and policies, leaving a void to be filled by the sensationalistic decline of literacy and the triumph of spectacle (Hedges, 2010). The values of Canadian society have been eclipsed by market interests of individualism, greed, dominance and control, potentially discouraging social change in many cases. The steady erosion and loss of information and data, media for communications pathways, and resources for participation in federal activities has effectively eroded democratic participation regardless of the potential for ICTs to contribute to and strengthen these democratic institutions in Canada. In a strong western democracy well equipped with advanced communications media, substantial barriers are being established to counter, confuse or eclipse the free flow of specific forms of information, forms that reflect Canadian values of empathy, cooperation, sustainability, freedoms of expression, strong democratic participation in community life, an important role for the state, and sustainably sharing our combined wealth of natural resources and human capital to make the planet a better place for all. This loss is being replaced by an increasing ability to communicate values of global market integration and economic competition as private interests flood the void left by public institutions.

This is not to suggest, however, that counter-revolutionary strategies come solely from more or less conventional socio-political approaches: digital media offer an enormous scope of opportunities to counter revolution and change on their own. Corcoran (2012) for instance, raises some interesting questions about Google searches, and by extension, the role of private telecommunication infrastructure in online discourse. Noting the advertisements that appear on Google searches when one performs a search using that platform for 'Robert Howarth' - a Cornell University professor who was the chief author of a paper that was critical of hydraulic fracturing - Corcoran questions the role(s) of search engines to maintain the staus quo. "Every time Professor Howarth's name was placed into a Google search engine, the first thing that appeared was an ad from ANGA [America's Natural Gas Alliance], devoted strictly to hampering the credibility of Howarth's research" (Corcoran, 2012). Similarly, in Canada, a search for 'Gasland' - a film critical of hydraulic fracturing in Canada - introduces the prominent advertisement for the Canadian Association of Petroleum Producers promoting the benefits of fracking and providing considerable industry literature about the economic importance of fossil fuel development in Canada. A search for 'life cycle costs of renewable energy' in Canada led (for this author) to an article on Phys.org (formerly Physorg.com, a "leading web-based science, research and technology news service") to an embedded advertisement for the Canadian Nuclear Association - a member of an industry which is coming under increasing pressure having had a considerable contract cancelled by a provincial government in recent months, is combating significant public opposition to the deep repository burial of high level nuclear waste in the Canadian Shield, and have watched global investments drop in the aftermath of the Fukushima incident in Japan - promoting nuclear energy generation.

Likewise, the use of many social media platforms and blog sites by social and environmental organisations employ networks whose business platform indirectly and often directly conflict with the goals of those organisations. One blog post about the report " Commitment Issues: Tar sands extraction invalidates Canada's obligations to the UNFCCC and undermines global climate change negotiations" by the Canadian Youth Delegation - the voice of the Canadian youth climate movement at international United Nations climate conferences - 
sprouted an advertisement for an SUV on the day the report was released - in other words, on the day when a high volume of visitors read the blog post.

It remains to be seen how social media and digital communications will unfold in the coming years. Despite the enormous potential to motivate change, counter forces are powerful, they extend far beyond the digital media, and there remains low awareness of class consciousness or the diverse strategic challenges confronting those in search of social change through ICTs.

\section{Social change - New ICTs and Values}

The messages that society projects defines how people behave, the structures we develop to satisfy our needs and wants, and the values and beliefs we set our fundamental operating principles upon (Stern, 2000; Stern et al, 1997), yet it is often the message we hear and discuss that are mostly paid attention to. In other words, as McLuhan (1964) stated, "...the medium is the message", implying that we tend to focus on the obvious at the expense of understanding structural factors that are more subtle, assumed and change slowly over time. However, the information in these messages is never static: they conform to and reinforce prevailing values, beliefs and worldviews, and are constantly in flux by the messages society receives from the world around us.

The messages ICTs are projecting today posit a more participatory governance, greater equalities and even sustainability, more widely and fairly distributing both the natural and social wealth of nations. Thus the source of much euphoria about their potential to engage social change.

Human behaviour is almost infinitely malleable, conforming to the dominant messages of society, and the infrastructures and choices that support the values and beliefs from which key messages crystalise (Mead, 1963; Naiman, 1997). Throughout the majority of human society, those messages established powerful beliefs, cultural practices and structures that prevented the 'Joneses' from getting ahead (Erdal and Whiten, 1996; Lenski and Lenski, 1978; Kaplan and Hill, 1985; Hawkes, O'Connell, \& Blurton-Jones, 1991). Those messages were reflected in values that held constraints to greed, competition, hoarding, control and leadership which were consistently reflected through deep understandings and appreciations of the natural world and its limits, and, equally, the importance of close social bonding, trust, equality, egalitarianism, sharing and cooperation. In these environments, cultural norms, practices and technologies evolved to ensure an equitable distribution of social wealth and a sustainable scale of the society (Gowdy, 1994; Livingston, 1994). ICTs can and do reflect all these values.

Today, however, the dominant social messages - transmitted, absorbed, opined, reinforced and affirmed through the largely privately owned ICT infrastructures - encourage getting ahead of the Joneses (Conca, 2001; Prodnick, 2012; Schröter, 2012;). These messages reflect beliefs in the mechanistic predictable functioning and control of the natural world, social relations and economic structures. Structures that support competition, greed, individual self-interest, materialism, inequality and hierarchies are rewarded (Daly and Cobb, 1994; Jackson, 2005; Manzerolle and Kjøsen, 2012; McGuigan, 2012). This has led to the perverse behaviour of economic growth as its own objective, resulting in accelerated material and energy demands (Daly, 1996; Jackson and Marks, 1999; Victor, 2009) along with increased social disparities between and across nations (Marmot et al, 1991; Marmot and Mustard, 1994; Marmot and Wilkinson, 2006; Raphael, 2007 \& 2002; Wilkinson and Pickett, 2009).

Federal policy decisions affecting media, communications and the use of ICTs in Canada merely reflect robust forces resisting the potential for ICTs to contribute to meaningful social change. With the support of firmly established social mechanisms and institutional structures, a dominant class appropriates for its own benefit a disproportionate amount of social wealth. Simultaneously, materially affluent nations expropriate a similarly disproportionate amount of natural wealth to perpetuate fundamentally unsustainable (both in a material and social sense) lifestyles (CSDH, 2008). ICTs merely project, reflect and reinforce these structures.

Paradoxically, it seems, the development of ICTs continue to focus on specific technologies, efficiencies and industries to stimulate economic growth and material expansionism, social exclusion, class divisions and wealth 
inequalities to more or less perpetuate the status quo (Aouragh, 2012; De Paoli and Storni, 2011; Garland and Harper, 2012; Heinonen, Jokinen and Jari, 2001; Heiskannn and Mikko, 2003; Lash, 2002). Despite calls and messages for societal change, and the widespread application of ICTs for democratic social change in Canada, these messages and applications are dwarfed by dominant messages and choices that reinforce prevailing institutional structures of growth, class hierarchies and inequalities, and mechanistic reductionism supported by a wide variety of policies and practices. Dominant values continue to permeate society, and these values are applied to manipulate what choices society is afforded to exploit through new ICT potentials.

It is the potential for ICTs to enable social change that have, to some extent, generated euphoria for ICTs to engage revolution and social change at local, national and global levels. Yet if the social structures and underlying values of society do not reflect deep social change, existing socio-political environments and established institutional structures function as an anchor that restrain the application of ICTs for social change.

To a similar extent, it is the perpetuation of existing structures that has generated this euphoria as businesses and industries beholden to the expansion of social media and other products and services of ICTs tend to over emphasize the benefits of ICTs and social media to achieve their own self-interested needs (Geels and Smit, 2000; Greiner, Radermacher, \& Rose, 1996; Heinonen, Jokinen, \& Kaivooja, 2001). As Upton Sinclair astutely noted, "'It is difficult to get a man to understand something, when his salary depends upon his not understanding it!" (Sinclair, 1935)

At the same time, very little attention is directed at the societal normalising ideals - the values and institutional structures - emerging from these new communication tools. This omission may have obscured an essential function of ICTs to unleash their anticipated transformational powers for social change - neglecting the message of the medium. That message - for participatory governance, equalities and more equal wealth and power distributions, sustainability, and cooperation and sharing - has been eclipsed by the competitive, individualistic, materialistic control beliefs that define prevailing global socio-economic structures. Despite the potential for ICTs to contribute to social change, the lack of attention to their higher order normalising features has made implementing this potential tenuous and often counterproductive. The results have often been the shading and distancing (Princen, 1997) of adverse consequences in more tightly coupled human-environment relationships vulnerable to increasingly intense systemic shocks (Homer-Dixon, 2000; 2006).

Social change and revolution may not be fully appreciated or engaged without understanding the role of society's values, beliefs and social structures (Sussman, 2012). ICTs greatest contribution to social change may therefore be derived from their transformative effects projecting the values and the messages necessary for desirable social change onto critical institutions and structures.

The true power of ICTs for social change and revolution cannot be viewed as a tool or set of tools or practices - the conventional mechanistic approach - such as social media per se. The transformational power of ICTs will be in the societal changes and processes they enable, and the power of those changes to demand the requisite transformations that motivate, advance and drive social change. But that change is more dependent upon social structures as they shape the ways in which the technology will, and in many cases, may be applied. ICTs have not yet achieved the escape velocity required for social change to exceed the gravitational forces exerted by global market values, hierarchies and competition.

\section{Conclusion}

Value structures and institutional arrangements tend to govern the ways in which technology will be applied. These factors also function to moderate those who would wish to or posit revolution and social change such as a more democratic nature to ICTs and social media. The political climate in Canada manifests a specific set of values inconsistent with deviation from market ideologies. ICTs serve all social actors, favouring those who have the greatest capacities to project their ideologies and values, and privileging prevailing structures. Those who have demonstrated a strong propensity to use all tools available at their disposal to maintain and strengthen their position generally subscribe to the values expressed by that social structure and believe only 
minor adjustments to the torque of events is required to ensure equality and sustainability. ICTs, by themselves, are unlikely to change the conditions that generate this social behaviour.

\section{References:}

Aouragh, Miriyam (2012). Social Media, Mediation and the Arab Revolutions. tripleC 10(2): 518-536.

Beresford, P. (2005). Redistributing profit and loss: The new economics of the market and social welfare. Critical Social Policy 25(4), 464-482.

Brennan, Jordan (2012). A Shrinking Universe: How Concentrated Corporate Power is Shaping Income Inequality in Canada. Canadian Centre for Policy Alternatives.

Canada (2012). Jobs, Growth and Long-Term Prosperity: Economic Action Plan 2012. Available at http://www.budget.gc.ca/2012/plan/pdf/Plan2012-eng.pdf

CBC (2009). PM shuts down Parliament until March: Tories trying to 'shut down democracy,' Liberal MP Goodale says, Canadian Broadcasting Corporation.

CBC (2012). 2015: Same Strategy, Different Path. Available at: http://cbc.radio-canada.ca/site/budget/en/ CBC, (2012a). CBC budget cut by $\$ 115 M$ over 3 years. Canadian Broadcasting Corporation.

Chase, Steven (2012). Just days after Harper's budget, the axe begins to fall. The Globe and Mail.

Conca, $K$. (2001). Consumption and environment in a global economy. Global Environmental

Politics, 1(3), 53-71.

Corcoran, Michael (2012). How Google is Helping the Gas Lobby Support Fracking. Truthout, November 15, 2012.

CRTC (2011). Canadian local over-the-air television stations have converted to digital television. Canadian Radio- $\quad$ television and Telecommunications Commission.

CPHA (2010). The Impact of Cancelling the Mandatory Long-Form Census on Health, Health Equity and Public Health. Canadian Public Health Association.

CSDH (2008). Closing the Gap in a Generation: Health Equity Through Action on the Social Determinants of Health. Final Report of the Commission on Social Determinants of Health. Geneva, World Health Organization.

Curry, Bill and Grant, Tavia (2012). Conservative cuts put half of Statscan jobs at risk. Available at: http://www.theglobeandmail.com/news/politics/conservative-cuts-put-half-of-statscan-jobs-at-risk/article41 06893/

Daly, H. E. (1996). Beyond growth: The economics of sustainable development. Boston: Beacon Press.

Daly, H. E., \& Cobb, J. B. Jr. (1994). For the common good: Redirecting the economy toward community, the environment, and a sustainable future. Boston: Beacon Press.

De Paoli, S. and Storni, C. (2011). "Produsage in hybrid networks: sociotechnical skills in the case of Arduino". $\quad$ New Review of Hypermedia and Multimedia, 17(1), 31-52.

Dunlop, Judith (2006). Privatization: How government promotes market-based solutions to social problems. Critical Social Work, Vol. 7, No. 2.

Ecojustice (2012). Legal Background: Canadian Environmental Assessment Act (2012) - Regulations.

Erdal, D., \& Whiten, A. (1996). Egalitarianism and Machiavellian intelligence in human evolution. In P. Me/lars \& K. Gibson (Eds.), Modelling the early human mind (139-50). Cambridge: McDonald Institute Monographs.

Garland, Christian and Harper, Stephen. (2012). Did Somebody Say Neoliberalism?: On the uses and Limitations of a Critical Concept in Media and Communication Studies. tripleC 10(2): 413 - 424.

Galloway, Gloria (2012). Budget cuts another victory in Tory war on information: opposition. The Globe and Mail.

Geels, F. W., \& Smit, W. A. (2000, November). Failed technology futures: Pitfalls and lessons from a historical survey. Futures 32(9-10), 867-85. 
Geist, Michael (2012). Everything You Always Wanted to Know About Lawful Access, But Were (Understandably) Afraid To Ask. Available at: http://www.michaelgeist.ca/content/view/6316/125/

Geist, Michael (2012a). Bill C-30 Isn't Dead Yet: Public Safety Allocates Millions for Lawful Access. Available at: http://Www.michaelgeist.ca/content/view/6471/196/

Geist, Michael (2012b). Public Safety Shuffle Could Allow for an Internet Surveillance Restart. http://www.michaelgeist.ca/content/view/6615/135/

Goldenberg, Suzanne (2012). Canada's PM Stephen Harper faces revolt by scientists. The Guardian. Available at: http://www.guardian.co.uk/environment/2012/jul/09/canada-stephen-harper-revolt-scientists

Gowdy, J. M. (1994). Coevolutionary economics: The economy, society and the environment. Boston: Kluwer Academic Publishers.

Grant, Tavia (2012). Budget cuts leave Statscan girding for fewer surveys, less staff. The Globe and Mail. Available at: http://www.theglobeandmail.com/news/politics/budget-cuts-leave-statscan-girding-for-fewer-surveys-less-staff/article4103776/

Greiner, C., Radermacher, F., \& Rose, T. (1996). Contributions of the information society to sustainable society. Ulm, Germany: FAW.

Hamilton, Gordon (2012). Green group splits to further advocacy goals. Vancouver Sun.

Hawkes, K., O'Connell, J. F., \& Blurton-Jones, N. G. (1991). Hunting income patterns among the Hadza; Big game, common goods, foraging goals and the evolution of the human diet. In $A$. Whiten \& $E$.

Widdowson (Eds.), Foraging strategies and natural diet of monkeys, apes and humans. Oxford, UK: Clarendon Press.

Hedges, Chris (2009). Empire of Illusion: The End of Literacy and the Triumph of Spectacle. Alfred A. Knopf, Canada.

Heinonen, Sirkka, Jokinen, Pekka, and Kaivo-oja, Jari (2001). The ecological transparency of the information society, Futures Volume: 33, Issue: 3-4, pp. 319-337, May.

Heiskanen, Eva and Jalas, Mikko (2003). Can Services Lead to Radical Eco-Efficiency Improvements? - A Review of the Debate and Evidence, Corporate Social Responsibility and Environmental management, 10,186 - 198, 2003.

Hennessey, Trish (2012). Taxing Times. Canadian Centre for Policy Alternatives. $\quad$ http://www.policyalternatives.ca/publications/commentary/taxing-times

Homer-Dixon, Thomas, (2000). The Ingenuity Gap : Facing the Economic, Environmental, and Other Challenges of an Increasingly Complex and Unpredictable World, New York : A.A. Knopf, 2000.

Homer-Dixon, Thomas (2006). The upside of down : catastrophe, creativity, and the renewal of civilization, Knopf Canada.

Horter, will (2012). Harper, staged conflicts and the path to victory.Dogwood Initiative. Available at: http://dogwoodinitiative.org/blog/harper-staged-conflicts

Hurtig, Mel (2011). The Truth about Canada. McClelland.

Jackson, Andrew (2012). CLC Analysis of the 2012 Federal Budget. Canadian Centre for Policy Alternatives.

Jackson, T. (2005). Live better by consuming less: Is there a "double dividend" in sustainable consumption? Journal of Industrial Ecology, 9(1-2), 19-36.

Jackson, T. and Marks, N. (1999). Consumption, Sustainable Welfare and Human Needs - With Reference to UK Expenditure Patterns Between 1954 and 1994, Ecological Economics, Vol. 28, No. 3, March.

Kaplan, H., \& Hill, K. (1985). Food sharing among ache foragers: Tests of explanatory hypotheses. Current Anthropology, 26, 223-45.

Labonte, Ronald and Schrecker, Ted (2007). Globalization and the Social Determinants of Health: Introduction and Methodological Background. Globalization and Health 3(5).

Lash, Scott. 2002. Critique of Information. London: Sage

Lenski, G. E., \& Lenski, J. (1978). Human societies: An introduction to macrosociology. New York: McGraw-Hill.

Livingston, J. (1994). Rogue primate. Toronto: Key Porter Books. 
Manzerolle, Vincent R. and Kjøsen, Atle Mikkola (2012). The Communication of Capital: Digital Media and the Logic of Acceleration. tripleC 10(2): 214 - 229.

Marmot, M. and Wilkinson, R. (2006) Social Determinants of Health, 2nd edition. Oxford University Press, Oxford, UK.

Marmot, M. G., Davey Smith, G, Stansfeld, S. A., Patel, C., North, F., \& Head, J. (1991). Health inequalities among British civil servants: The Whitehall II study. Lancet, 337, 1387-93.

Marmot, M. G., \& Mustard, J. F. (1994). Coronary heart disease from a population perspective. In R. G. Evans, M. L. Barer, \& T. R. Marmor (Eds.), Why are some people healthy and others not? The determinants of health of populations. New York: A. de Gruyter.

McCarthy, Shawn (2012). CRA audits charitable status of Tides Canada amid Tory attack. The Globe and Mail.

McGuigan, Jim (2012). The Coolness of Capitalism Today. tripleC 10(2): 425 - 438.

McLuhan, Marshall (1964). Understanding Media, Routledge, London.

Mead, Margaret (1963). Sex and Temperament in Three Primitive Societies, New York, William Morrow.

Mosco, Vincent and McKercher, Catherine (2006). Convergence Bites Back: Labour Struggles in the Canadian Communication Industry. Canadian Jopurnal of Communications, Vol. 31, No. 3

http://www.cjc-online.ca/index.php/journal/issue/view/116/showToc

Naiman, Joanne (1997). How Societies Work; Class, Power and Change in a Canadian Context, Irwin Publishing.

Nature (2012) Editorial, Nature 483, 6 (01 March 2012)

OPC (2012). We must remain Ever Vigilant in preserving our privacy and promoting access: Commissioner

Cavoukian. Office of Privacy Commissioner for Ontario. Available at: http://www.ipc.on.ca/images/Resources/2012-06-04-2011_Annual_Report.pdf

Open Media (no date). Don't sever Canada's digital lifeline. Available: http://openmedia.ca/lifeline

Princen, $T$ (1997). The Shading and Distancing of Commerce: When Institutionalization is Not Enough, Ecological Economics 20, 235 - 253.

Prodnik, Jernej (2012). A Note on the Ongoing Processes of Commodification: From the Audience Commodity to the Social Factory. tripleC 10(2): 274-301.

Rabson, Mia (2012). Scientists decry 'war on knowledge' in Ottawa. Winnipeg Freepress. Available at: http://Www.winnipegfreepress.com/breakingnews/Scientists-decry-war-on-knowledge-in-Ottawa-16195021 5.html

Ramos, Howard and Ron, James (2012). Funding cuts could unshackle Canadian civil society. The Toronto Star.

Raphael, D. (2007). Poverty and policy in Canada: Implications for health and quality of life. Toronto: Canadian Scholars' Press Incorporated.

Raphael, D. (2002). Social justice is good for our hearts: Why societal factors - not lifestyles-are major causes of heart disease in Canada and elsewhere. Toronto: Center for Social Justice Foundation for Research and Education.

Reynolds, Keith (2012). Harper's Methodical Campaign to Silence Democracy. The Tyee, August 18, 2012.

Schröter, Jens (2012). The Internet and "Frictionless Capitalism". tripleC 10(2): 302-312.

Senate (2006). Final Report of the Canadian News Media, Volume 1 and 2, Standing Senate Committee on Transport and Communications.

Sinclair, Upton (1935). I, Candidate for Governor: And How I Got Licked (1935), University of California Press, London, 1935.

Smith, Teresa (2012). Scientists stage mock funeral to protest cuts to research. Post Media Network, Inc. Available at: http://www.canada.com/business/Scientists+stage+mock+funeral+protest+cuts+research/6913396/story.ht $\mathrm{ml}$

Stern, P. C. (2000). Toward a coherent theory of environmentally significant behavior. Journal of Social Issues,

$56(3), 407-24$ 
Stern, P. C., Dietz, T., Ruttan, V. W., Socolow, R. H., \& Sweeney, J. L. (1997). Environmentally significant consumption: Research directions. Washington, DC: National Academy Press.

Sussman, Gerald (2012). Systemic Propaganda as Ideology and Productive Exchange. tripleC 10(2): $474-487$.

Suzuki, David (2012). Will Canada's war on science plunge us into a new Dark Age? The Star, Monday November 12, 2012. Available at: http://www.thestar.com/opinion/article/1286713--will-canada-s-war-on-science-plunge-us-into-a-new-dark -age

Victor, Peter (2009). Managing without Growth: Slower by Design, Not Disaster, 2009. : - Edward Elgar. Northampton, MA.

Wilkinson, Richard and Pickett, Kate (2009). The Spirit Level: Why Equality is Better for Everyone. Penguin, March 2009. 